\title{
Chromosomal variability in the wild ornamental species of Symphysodon (Perciformes: Cichlidae) from Amazon
}

\author{
Débora R. Mesquita ${ }^{1}$, Jorge I. R. Porto ${ }^{2}$ and Eliana Feldberg ${ }^{2}$
}

Cytogenetic studies were conducted on three discus species which inhabit the Amazon in Brazil: Symphysodon haraldi from Manacapuru, S. aequifasciatus from Tefé and S. discus from Barcelos. All individuals showed $2 \mathrm{n}=60$ chromosomes, most of them biarmed. No sexual chromosomal heteromorphism was verified. However, different karyotypic formulae, owing to the presence of subtelocentric chromosomes, were verified for S. aequifasciatus and S. discus. One of the karyotypic formulae from S. aequifasciatus (cytotype 2) differs from the others, due to one of the homologues in the first chromosome pair being significantly larger than the other. A large variability was observed toward the nucleolar organizer regions (NOR) of $S$. haraldi and S. aequifasciatus. Although the number of silver-stained blocks varied from 2 to 5 , confirming different NOR patterns, at least seven homologue pairs were involved with NORs. In S. discus only two marks were observed, however two chromosome pairs were involved, characterizing a multiple NOR system for the three species. The heterochromatic blocks were mainly located in the pericentromeric region of all chromosomes but, in some of them, they are also located in the proximal regions, both in the short and long arms. Moreover, in the cytotype 2 from S. aequifasciatus, an interstitial heterochromatic block was observed on the long arm of the largest homologue of the first pair. A direct comparison of karyotypes from more related genera (Heros, Uaru, Mesonauta and Pterophyllum), makes it clear that a succession of chromosomal rearrangements, mainly pericentric inversions, translocations and fissions/fusions occurred resulting in the present diploid number and intraspecific karyological variability found in Symphysodon.

Estudos citogenéticos foram conduzidos em três espécies de acará-disco que habitam a Amazônia no Brasil: Symphysodon haraldi coletada em Manacapuru, S. aequifasciatus coletada em Tefé e S. discus em Barcelos. Todos os indivíduos apresentaram $2 \mathrm{n}=60$ cromossomos, a maioria deles com dois braços. Heteromorfismo de cromossomos sexuais não foi detectado. Porém, diferentes fórmulas cariotípicas, devido à presença de cromossomos subtelocêntricos, foram verificadas em S. aequifasciatus e em S. discus. Uma das fórmulas cariotípicas (citótipo 2) de S. aequifasciatus difere das outras, devido a um dos homólogos do primeiro par cromossômico ser significativamente maior que o outro. Uma grande variabilidade foi observada em relação à região organizadora do nucléolo (RON) de $S$. haraldi e de S. aequifasciatus. Embora, o número de marcações coradas por Nitrato de Prata variou de 2 a 5, confirmando diferentes padrões de RON, pelo menos sete pares de homólogos foram envolvidos com a RON. Em S. discus foram observadas apenas duas marcas, envolvendo, contudo, dois pares de cromossomos, caracterizando um sistema de RONs múltiplas, para as três espécies. Os blocos heterocromáticos estão localizados, principalmente, na região pericentromérica de todos os cromossomos, sendo que alguns deles também foram observados em regiões próximas aos centrômeros, tanto nos braços curtos quanto nos braços longos. Além disso, no citótipo 2 de S. aequifasciatus, um bloco heterocromático foi observado, intersticialmente no braço longo do maior homólogo do primeiro par. Uma comparação direta dos cariótipos dos gêneros mais relacionados (Heros, Uaru, Mesonauta e Pterophyllum), deixa claro que ocorreu uma sucessão de rearranjos cromossômicos, principalmente inversões pericêntricas, translocações e fissões/fusões, que resultou no presente número diplóide e na variabilidade cariotípica encontrada em Symphysodon.

Key words: Discus, Cytogenetics, Polymorphism, Microchromosomes, Multiple NORs.

${ }^{1}$ Centro Federal de Educação Tecnológica do Amazonas, Coordenação de Ciências Biológicas. deborarabello@yahoo.com.br

${ }^{2}$ Instituto Nacional de Pesquisas da Amazônia, Coordenação de Pesquisas em Biologia Aquática, Cx Postal 478, 69011-970 Manaus, Amazonas, Brazil. (JIRP) jirporto@inpa.gov.br; (EF) feldberg@inpa.gov.br 


\section{Introduction}

In Brazil, the Amazon basin is responsible for more than $90 \%$ of all ornamental fish exported to North American, European and Asian markets and the revenues generated by this trade is valued at approximately 3 million US\$ annually (Chao, 2001). The discus fish is characterized by a colourful and compressed disk-shaped body that captures the attention of aquarium hobbyists worldwide, making it one of the most demanded Amazonian fish in the ornamental fish trade (Goldstein, 1973; Silva \& Kotlar, 1980; Axelrod, 1995). Among the top 10 of the main freshwater ornamental fishes certainly the cichlid discus is enrolled on it.

Previously, some authors had suggested that Symphysodon contained two species split into five subspecies (Silva \& Kotlar, 1980), while others suggested the existence of only a single species of Symphysodon (Mazeroll \& Weiss (1995). According to recent publications, Symphysodon currently includes three species: S. discus Heckel, 1840 (Heckel Discus), S. aequifasciatus Pellegrin, 1904 (Blue or Brown Discus) and S. tarzoo Lyons, 1959 (Green Discus) (Ready et al., 2006) or S. discus, S. haraldi Schultz, 1960 and S. aequifasciatus (Bleher, 2006; Bleher et al., 2007). Ready's and Bleher's publications refer to the Heckel Discus as S. discus. However, Ready et al. (2006) refer to the Green discus as $S$. tarzoo, while Bleher et al. (2007) refer to it as S. aequifasciatus. Ready et al. refer to the Blue and Brown discus as $S$. aequifasciatus, while Bleher et al. recognize them as $S$. haraldi.

Endemic to the Amazon Basin, Symphysodon occurs in tributaries of the rio Amazonas. Heckel Discus is found primarily in the tributaries of the rios Negro, Branco, Purus, Abacaxis and Trombetas, whereas Green Discus occurs in the Western Amazon, and Blue and Brown Discus has the widest distribution occurring along almost the entire length of the rio Amazonas from $49^{\circ}$ to $70^{\circ}$ longitude West (Ready et al., 2006; Bleher et al., 2007).

Despite the large importance of discus fish in the ornamental fish industry, due mainly to a well known breeding program that introduces a half dozen new strains every year, only a handful of genetic studies have been conducted. Over the last 40 years, the chromosomal structure (Ohno \& Atkin, 1966; Thompson, 1979; Takai et al., 2002) and cellular DNA content (Ohno \& Atkin, 1966) of S. aequifasciatus have been described. More recently, the DNA stretches of $S$. aequifasciatus were either studied to analyze the different strains, with the use of RAPD, or to provide the molecular relationship among genera, by using DNA sequencing (Koh et al., 1999; Farias et al., 2000; 2001; Degani, 2003). Currently, analysis of mitochondrial DNA (control region and cytochrome b) has revealed genetically distinct clades/lineages of Symphysodon (Ready et al., 2006; Bleher et al., 2007) and evidence of introgressive hybridization. The aim of this work is to present an evaluation of karyotypic data from "wild discus”, and to discuss the cytogenetic data from a karyo-evolutionary perspective.

\section{Material and Methods}

Discus specimens were collected from natural habitat in the Amazon Basin and were identified according to diagnostic keys provided by Ready et al. (2006), Bleher (2006) and Bleher et al. (2007), and we opted to follow Bleher's taxonomy, i.e., S. aequifasciatus (Green discus), S. haraldi (Brown/Blue discus) and $S$. discus (Heckel discus).

The species collected were: Symphysodon aequifasciatus (11 males and five females) from lago Bauana in the rio Tefé system; S. haraldi (10 males and 10 females) from the rio Manacapuru; and, S. discus (two males, five females and one of indefinite sex) from the Boi-boi Stream, in the middle rio Negro, located directly in front of the town of Barcelos (Fig. 1). The specimens from lago Bauana were identified as belonging to $S$. aequifasciatus, considering the extent of its geographic distribution (Ready et al., 2006; Bleher, 2006; Bleher et al., 2007) and ongoing DNA analysis (Izeni Farias, pers. comun.). However, these specimens, after preservation in formalin, did not present $S$. aequifasciatus's main diagnostic features, i.e., the presence of red spots on the anal fin and/or on the body.

Voucher specimens were deposited in the Fish Collection at the Instituto Nacional de Pesquisas da Amazônia (INPA) in Manaus, Amazonas State, Brazil: INPA 28582 Symphysodon aequifasciatus (Tefé), INPA 28583 Symphysodon haraldi (Manacapuru), and INPA 28584 Symphysodon discus (Barcelos).

Chromosomal preparations were obtained from kidney cells, following the "air-drying” technique of Bertollo et al. (1978). Approximately 30 metaphasic plates were analyzed from each individual. Nucleolar organizer regions (NORs) were identified by silver nitrate according to Howell \& Black (1980) and the $\mathrm{C}$ bands utilizing the barium hydroxide treatment (Sumner, 1972). Whenever possible, slides were stained sequentially with Giemsa, C-banding and silver nitrate solution according to procedures described in Centofante et al. (2002).

The karyotype was determined for each specimen and a total of nine were measured (five from Manacapuru, two from Tefé and two from Barcelos). However, the last ten pairs were measured for all individuals, due to their small size. Chromosome morphology was based on arm ratios (long arm length divided by short arm length) as proposed by Levan et al. (1964). The measurements were made with the help of a drytip compass and a pachymeter and arranged in a size-decreasing order. Chromosomes were classified in two groups, as proposed by Thompson (1979) to Cichlidae: metacentricsubmetacentric (m-sm) and subtelocentric-acrocentric (st-a). For a inter- and intraspecific comparison purpose we opted to organize the karyotype in size decreasing order. The fun- 
damental number (FN) was determined by considering m-sm with two arms, st-a and microchromosomes with one arm.

\section{Results}

All individuals, male and female, possessed a diploid number equal to 60 chromosomes. There were no differences in chromosome morphology between males and females in the three species. However, different intra-populational karyotypic formulae were found, owing to the presence of subtelocentric chromosomes, indicating the occurrence of chromosome polymorphism among the individuals from Symphysodon aequifasciatus and S. discus, but not from S. haraldi. In Symphysodon haraldi a single karyotypic formula was observed since all specimens presented $52 \mathrm{~m}$-sm + 4 st-a (26, 27 pairs) +4 mi(29, 30 pairs) and $N F=112$ (Fig. 2A).

In Symphysodon aequifasciatus two cytotypes were observed. In the first, seven males and five females presented $48 \mathrm{~m}$-sm +8 st-a $(8,15,27,28$ pairs $)+4 \mathrm{mi}$ (29, 30 pairs), NF= 108 (Cytotype 1), while in the second, four males presented $50 \mathrm{~m}-\mathrm{sm}+6 \mathrm{st}-\mathrm{a}(16,26,27$ pairs $)+4 \mathrm{mi}$ (29, 30 pairs), $\mathrm{NF}=110$ (Cytotype 2). Besides the distinct karyotypic formula, the differences between both cytotypes were due to one of the homologues in the first chromosome pair being significantly larger than the other $(\mathrm{CR} \%=8.54 / 7.73)$ and the size differences between 3rd and 4th chromosome pairs (Fig. 2B, 2C).
In Symphysodon discus two cytotypes were observed. In the first, one male, five females and one undefined sex presented $50 \mathrm{~m}$-sm +10 st-a $(10,27,28,29,30$ pairs $), N F=110$ (Cytotype1) and one male presented $54 \mathrm{~m}-\mathrm{sm}+6$ st-a (28, 29, 30 pairs), NF=114 (Cytotype2) (Fig. 2D, 2E).

The Ag-NORs revealed an interesting pattern for Symphysodon species. Symphysodon haraldi presented two active NOR sites in $68 \%$ of analyzed cells however, the active NOR sites varied of two to five, while $S$. aequifasciatus presented the modal number of two active NOR sites in $93 \%$ of analyzed cells, except for a single specimen that exclusively presented three active NORs. The NORs occupied the whole short arm or its terminal end, and, at times, the terminal portion of the long arms. Despite this, based on the size and morphology of the NOR-bearing chromosome, at least seven homologue pairs were apparently involved in the nucleolar organization of $S$. haraldi $\left(3^{\text {rd }}, 5^{\text {th }}, 10^{\text {th }}, 11^{\text {th }}, 21^{\text {st }}, 22^{\text {nd }}\right)$ and $S$. aequifasciatus $\left(5^{\text {th }}, 10^{\text {th }}, 11^{\text {th }}, 15^{\text {th }}, 21^{\text {st }}, 22^{\text {nd }}\right)$. Five of these chromosome NOR carriers were shared between $S$. haraldi and $S$. aequifasciatus, and each one had one exclusive pair (Fig.3 A, B, C and Fig. 4A, B). Conversely, S. discus presented only two NOR-bearing chromosomes (100\% of analyzed cells), being the Ag-NORs always located on the short arms. However, in seven individuals (cytotype 1) the Ag-NORs were assigned to $18^{\text {th }}$ pair (single NOR phenotype) and in one individual (cytotype 2 ) to the $18^{\text {th }}$ and $24^{\text {th }}$ (multiple NOR pheno-
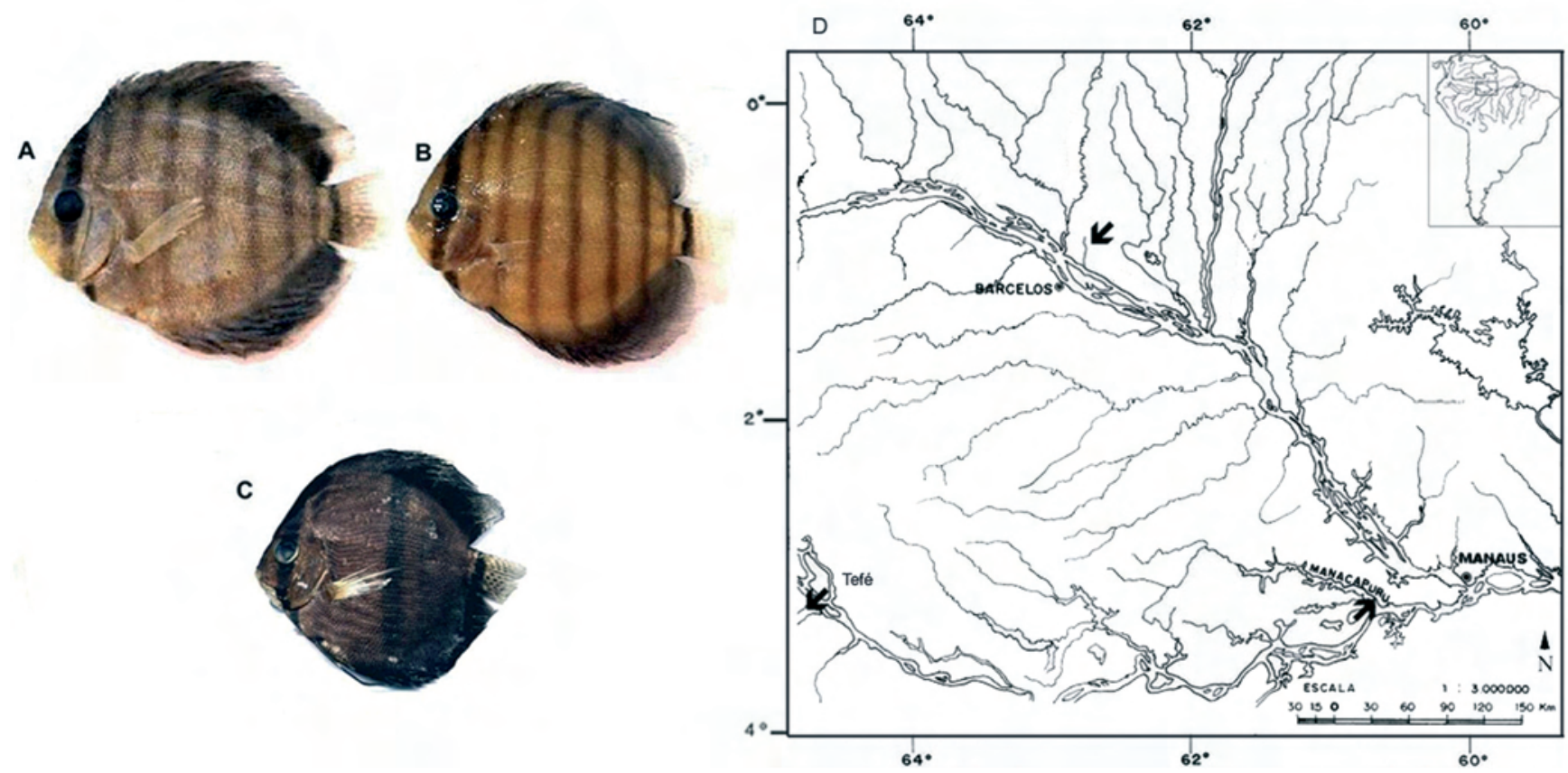

Fig. 1. Photo of analyzed species: (A) Symphysodon haraldi from Manacapuru, (B) S. aequifasciatus from Tefé, (C) S. discus from Barcelos, and map showing the location of discus sampling sites. 

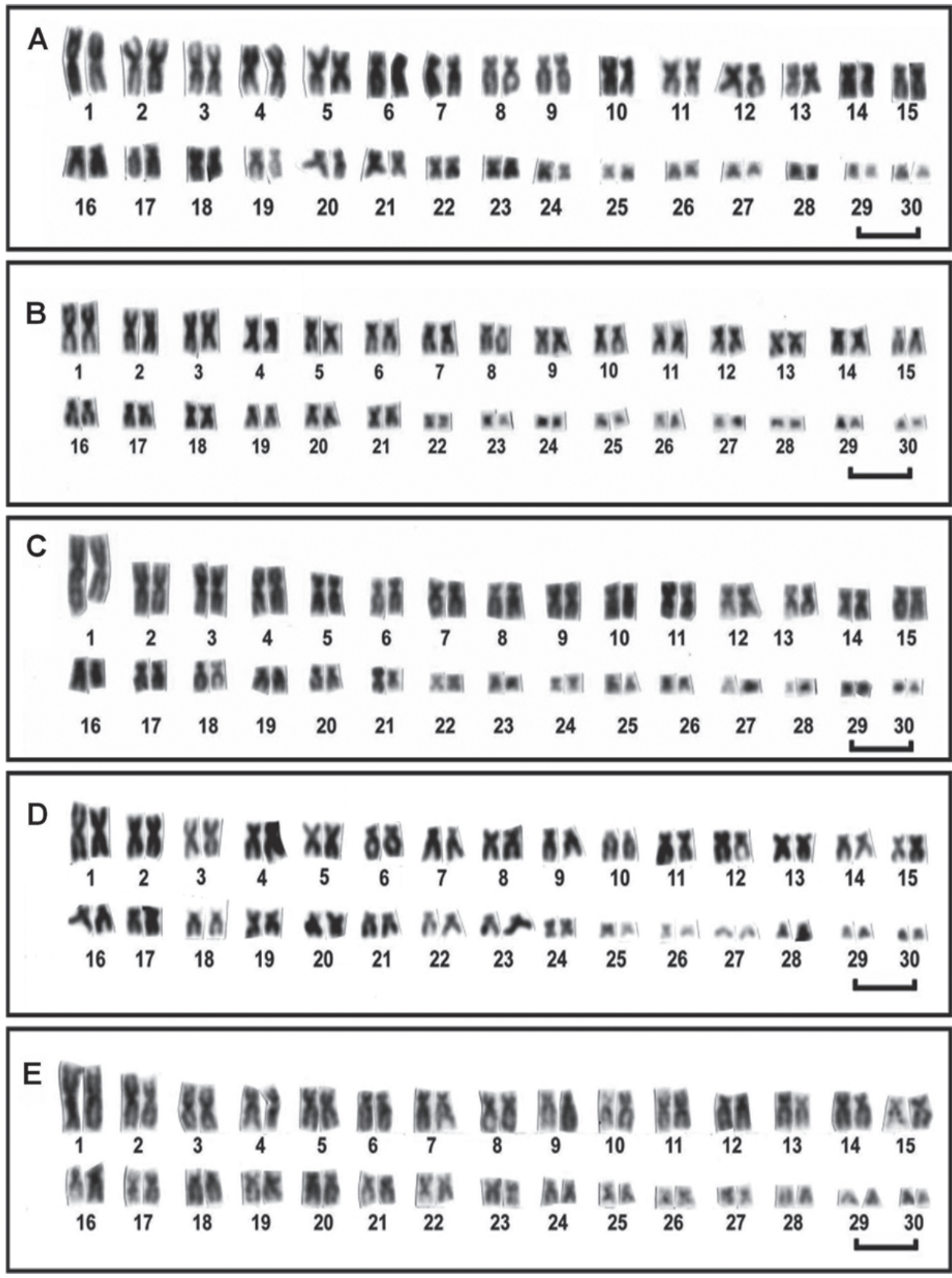

Fig. 2. Conventional Giemsa-stained karyotypes: (A) Symphysodon haraldi from Manacapuru, the pairs 26-27 are st-a and 2930 are microchromosomes; (B) S. aequifasciatus from Tefé (cytotype 1), the pairs 8, 15, 26 and 27 are st-a and 29-30 are microchromosomes; (C) S. aequifasciatus from Tefé (cytotype 2), the pairs 16, 26 and 27 are st-a and 29-30 are microchromosomes; (D) S. discus from Barcelos (cytotype 1), the pairs10, 27-30 are st-a; (E) S. discus from Barcelos (cytotype 2), the pairs 28-30 are st-a. Scale bar represents $5 \mu \mathrm{m}$. 

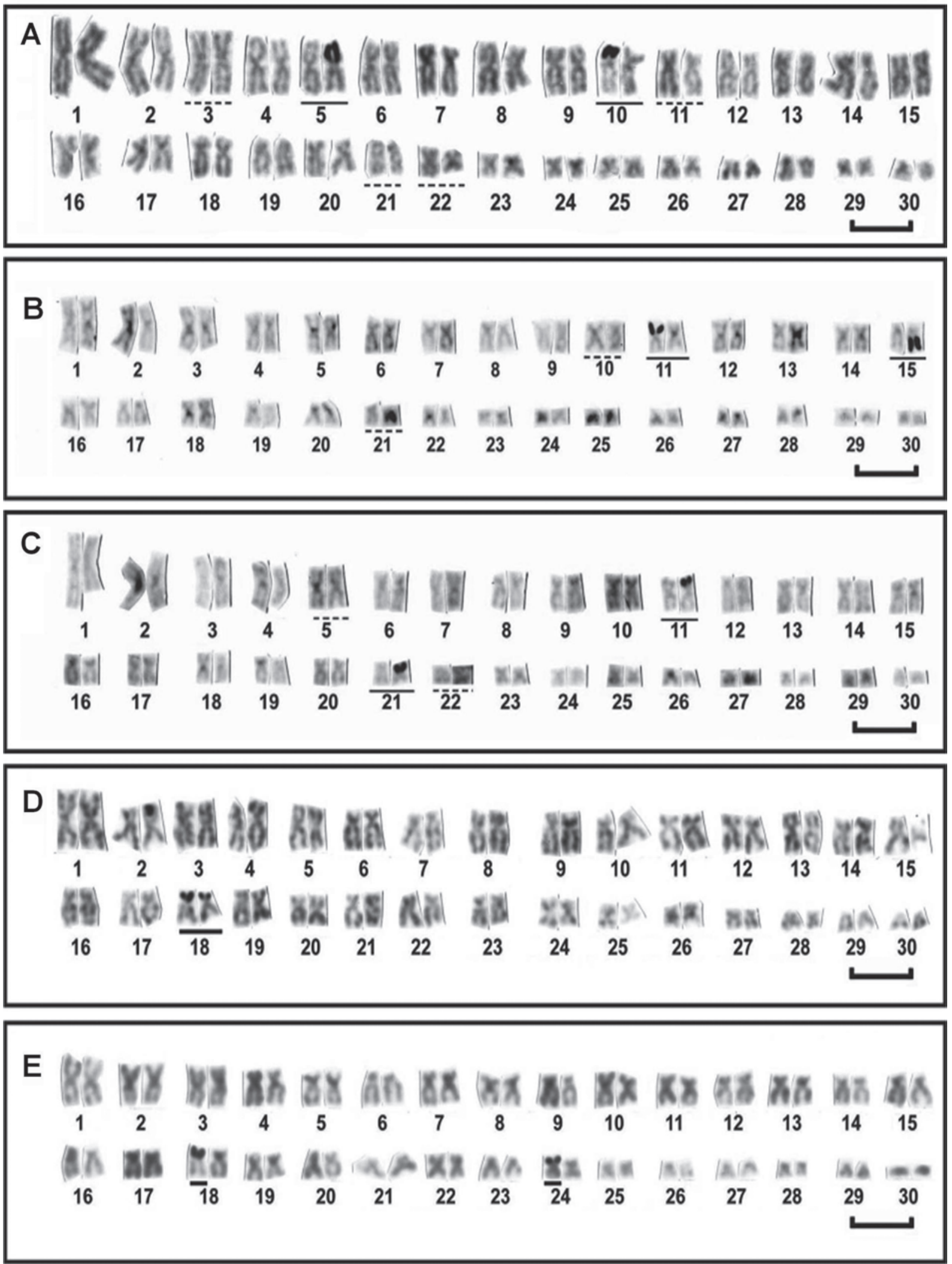

Fig. 3. Karyotypes stained with silver nitrate: (A) Symphysodon haraldi from Manacapuru; (B) S. aequifasciatus from Tefé (cytotype 1); (C) S. aequifasciatus from Tefé (cytotype 2); (D) S. discus from Barcelos (cytotype 1); (E) S. discus from Barcelos (cytotype 2). The underlined pairs are involved with the NORs. Scale bar represents $5 \mu \mathrm{m}$. 


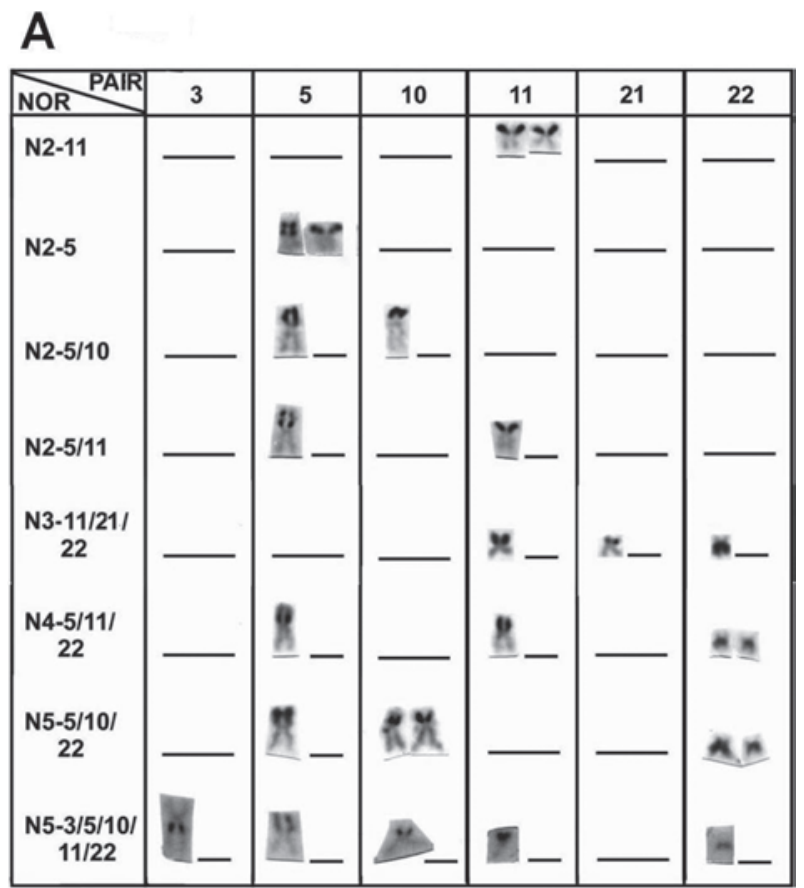

B
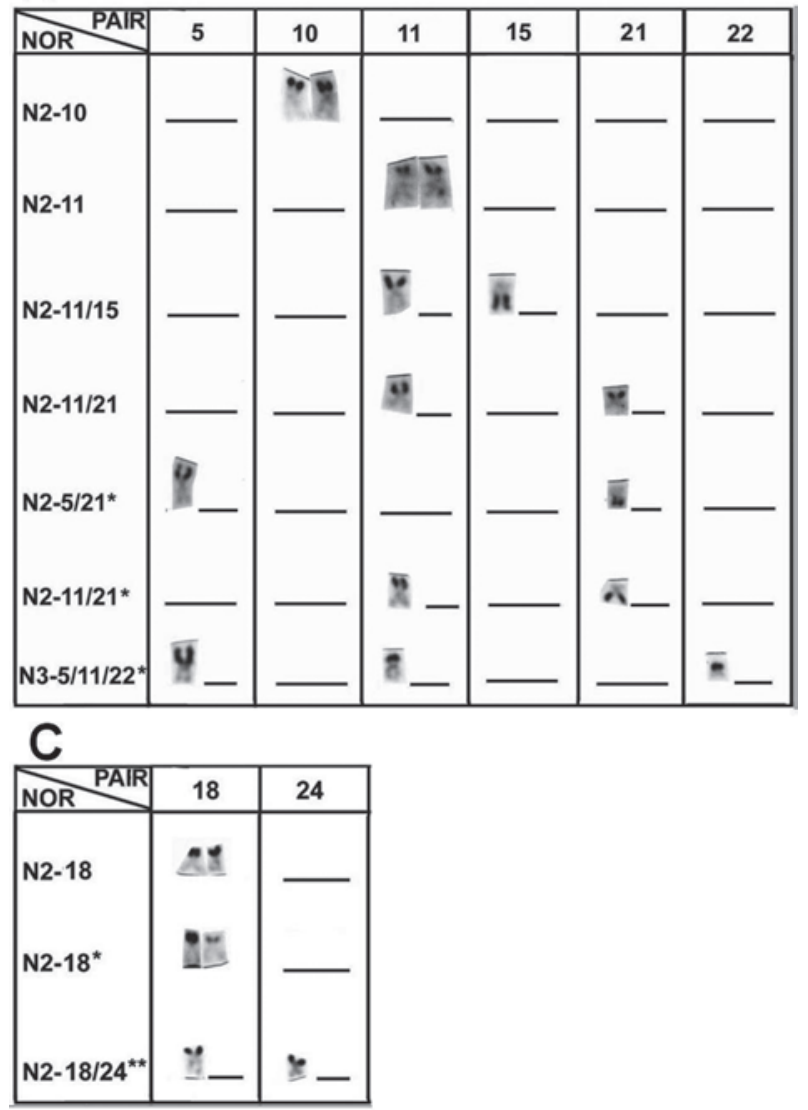

Fig. 4. NORs phenotypes (Nx-xx) corresponding to the numbers of observed NORs and their karyotypic position (pair) seen in: (A) Symphysodon haraldi from Manacapuru; (B) $S$. aequifasciatus from Tefé, * represents cytotype 2; (C) S. discus from Barcelos, * represents heteromorphic NOR, ** represents cytotype 2 . type). Further, the $18^{\text {th }}$ pair presented a size polymorphism for the NOR (Fig. 3 D, E and Fig. 4C). Considering the number of Ag-NORs phenotypes observed in Symphysodon haraldi, S. aequifasciatus and $S$. discus, they presented up to eight, seven, and three Ag-NOR phenotypes, respectively (Fig. 4A, B, C).

All individuals have heterochromatic blocks, which were quite evident on the pericentromeric regions of all chromosomes, and on many of them these blocks were also found in the proximal regions of both arms (Fig. 5 A, B, C, D, E). In $S$. aequifasciatus, which showed one of the homologues in the first chromosome pair being significantly larger than the other, presented one interstitial heterochromatic block on the long arm (Fig. 5 C).

\section{Discussion}

The cichlids belong to the Perciformes group of fish which present a bimodal diploid number: 48 chromosomes in New World species and 44 in Old World species (reviewed in Feldberg et al., 2003). Morphological and molecular studies of the Cichlidae family place Symphysodon in the subfamily Cichlasomatinae, in the Heroini tribe (Kullander, 1998; Farias et al., 2000; 2001). Symphysodon is closely related to a group of cichlids which encompasses the genera Heros, Mesonauta, Pterophyllum, and Uaru. Except for the last genus in which the species possesses 46 chromosomes, the other ones all possess 48. Surprisingly, the diploid number found in the three species of Symphysodon is 60 chromosomes (Ohno \& Atkin, 1966; Thompson, 1979; Takai et al., 2002; present work).

In a broad sense, fish cytotaxonomy is the study of the relationships and classification of species using both classical systematic techniques and comparative studies of chromosomes. In the present paper, we show that Symphysodon aequifasciatus, S. haraldi and S. discus present the most derived karyotype amongst all cichlids given the pronounced differences observed in the diploid number $(2 \mathrm{n}=60$ chromosomes) and fundamental number, when compared to the 135 cichlid species karyotyped so far (Feldberg et al., 2003). By possessing a high diploid number and presenting most chromosomes with two arms, their karyotypic structures differ in many aspects from the presumed ancestral karyotype of all cichlids (i.e. $2 \mathrm{n}=48$ chromosomes, mostly uniarmed) (Thompson, 1979; Feldberg et al., 2003).

Thompson $(1976 ; 1979)$ was the first to suggest that $S$. aequifasciatus presents the most aberrant karyotype found among all the neotropical cichlids, and that this karyotype probably originated from a succession of events, including polyploidization.

A direct comparison of karyotypes from all related genera (Heroini) makes it clear that the occurrence of a succession of chromosomal rearrangements, mainly pericentric inversions, 

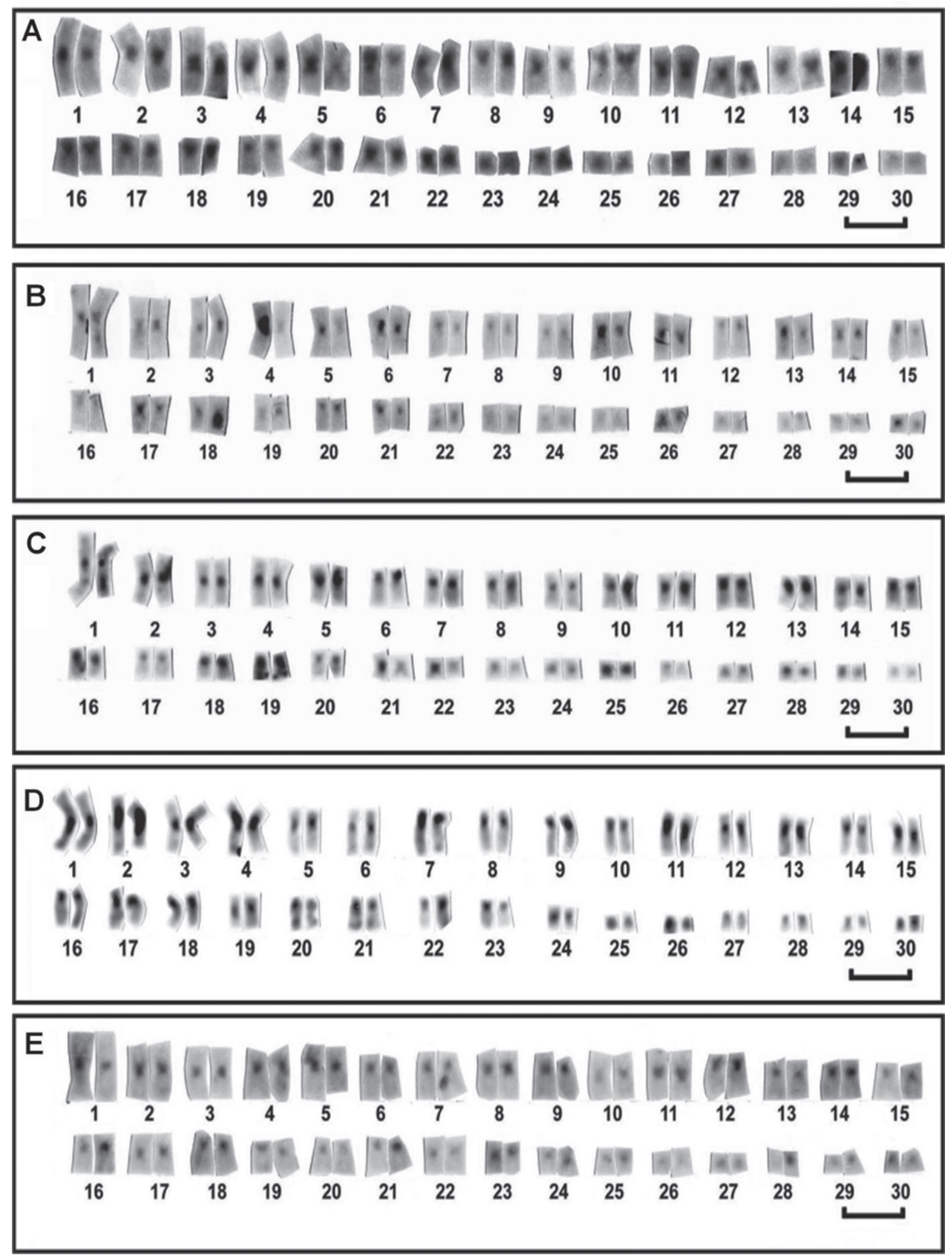

Fig. 5. Karyotypes with C-bands: (A) Symphysodon haraldi from Manacapuru; (B) S. aequifasciatus from Tefé (cytotype 1); (C) S. aequifasciatus from Tefé (cytotype 2); (D) S. discus from Barcelos (cytotype 1); (E) S. discus from Barcelos (cytotype 2). Scale bar represents $5 \mu \mathrm{m}$. 
translocations and fission/fusions was necessary in order to create the karyotype found in Symphysodon. This sequence of events could account for the appearance of the m-sm chromosomes and to explain the reduced size of some chromosomes.

Ohno \& Atkin (1966) and Thompson (1979) noticed that Symphysodon aequifasciatus presented some pairs of minute chromosomes. The wild forms of S. aequifasciatus, S. haraldi and $S$. discus karyotyped in the present paper also presented minute chromosomes. Such asymmetry of macro and microchromosomes was evident in the karyotype of Symphysodon, where at least nine last pairs of minute chromosomes in S. aequifasciatus, and at least six pairs in both $S$. haraldi and S. discus were visible.

Microchromosomes are tiny chromosomes (Denton, 1973) which vary in size between 0.5 and $1.5 \mu \mathrm{m}$ (Mattey, 1975). They visually resemble a metaphase dot, in which it is not possible to identify the centromere nor assign a chromosome morphology (Tegelström \& Ryttman, 1981). Microchromosomes can present constitutive heterochromatin and nucleolar organizer regions (Tegelström \& Ryttman, 1981; Tegelström et al., 1983; De Lucca, 1983; Fillon et al., 1998; Goldschmidt et al., 2000). Considering these descriptions, in Symphysodon aequifasciatus and in S. haraldi the pairs 29 and 30 were considered microchromosomes, as they did not possess a distinctive morphology in all metaphasic plates. Conversely, in S. discus, the size of the minute chromosomes resembled that of a microchromosome. However, it was possible to identify their centromeric position and, consequently, they were not characterized as microchromosomes. This characteristic differentiates $S$. discus from the other two species.

Microchromosomes in vertebrates are rare, being found mainly in reptiles and birds (Gutierrez \& Bolanos, 1980; Bull \& Legler, 1980; Tegelström \& Ryttman, 1981). In fish, microchromosomes have been described in such primitive species as Scaphirhynchus platorhynchus (Acipenseriformes), Hydrolagus colliei (Chimaeriformes) and Lepisosteus productus (Lepisosteiformes) (Ohno et al., 1969). The fact that minute chromosomes have been found in Symphysodon strongly suggests that rearrangements, namely fission/fusions, pericentric inversions and translocations, were necessary for the derivative karyotype of these species to evolve.

The difference between the cytotypes was related to the number of chromosomes found in m-sm and st-a types, indicating the occurrence of polymorphism within $S$. aequifasciatus and S. discus, but not within S. haraldi. Also, the cytotype 2 in four individuals of $S$. aequifasciatus differs from the others in that one homologue of the first pair presents a duplication or a translocation on the long arm, con- firmed by C-band. Interestingly, this chromosome with interstitial C-band has never been seen before in homozigose and was detected in both males and females (unpublished data).

Regarding the NORs, S. haraldi and S. aequifasciatus presented a high degree of variability relative to the NORbearing chromosomes. Intra and inter-individual variation was significantly higher in Symphysodon haraldi and, additionally, was also found on the activation of the rDNA sites in $S$. aequifasciatus. Conversely, S. discus always presented two NOR-bearing chromosomes. However, on cytotype 1 these were only one pair $\left(18^{\text {th }}\right)$, and on cytotype 2 the markings were displayed on two non-homologue chromosomes $\left(18^{\text {th }}\right.$ and $\left.24^{\text {th }}\right)$, thus proving the multiple NOR characteristic in three species. The results of the present study showed clearly that differences among chromosomal NOR patterns in Symphysodon species exist, and these NORs patterns are taxonomically informative.

This variability relative to the number of NOR-bearing chromosomes could be due to a difference in activity among the homologues or a difference in the number of ribosomal cistrons, due to an unequal disassociation during cell division or translocations involving these chromosomes. It was still possible to find a difference in the NOR active site position of the same chromosome for the different cytotypes, suggesting the occurrence of pericentric inversions in NORbearing chromosomes.

According to Feldberg et al. (2003), Cichlidae may be characterised as a family presenting a single NOR system (only one pair of NORs) located on the larger chromosome of the complement. This feature appears to be a plesiomorphic characteristic for cichlids. Therefore, the three species possess a derived chromosomal structure presenting multiple NORs. Further, Symphysodon haraldi, S. aequifasciatus and S. discus were characterised by the presence of eight, seven, and three Ag-NOR phenotypes, respectively (Fig. 4). Thus we considered this NOR polymorphism as a product of distinct activation of presence/absence type. The multiplicity of NORs showing intra- and interindividual differences in the number and localization of the rDNA genes have been observed in many Neotropical fish species, however not in Neotropical cichlids.

Cytogenetic, molecular and morphological data suggest a large variability in the genus Symphysodon (Kokoscha \& Greven, 1996; Koh et al., 1999; Ready et al., 2006; Bleher et al., 2007). Therefore, studies of Symphysodon in its geographic distribution, making use of molecular cytogenetic together with molecular, morphological, taxonomic and systematic studies, could contribute to a better understanding of the complexity existing in this genus. 


\section{Acknowledgements}

This work was supported by the Instituto Nacional de Pesquisas da Amazônia (INPA), through the Research Institutional Projects (PPI 2-3450), Conselho Nacional de Desenvolvimento Científico e Tecnológico (CNPq)/Programa de apoio a Núcleos de Excelência em Ciência e Tecnologia (PRONEX) and Programa Norte de Pós-graduação (PNOPG). D.R.Mesquita received graduation scholarships from CAPES - UFSCar/UFAM. The authors are grateful to Dr. J. A. S. Zuanon for assistance in identifying the species, to $\mathrm{K}$. Yamamoto (K2-Peixes Tropicais) for providing additional specimens, to M. C. Gross for helpful comments on early drafts of the manuscript, to A. S. Teixeira for his suggestions and to B. Marshall for revision of the English.

\section{Literature Cited}

Axelrod, H. R. 1995. Dr. Axelrod's mini-atlas of freshwater aquarium fishes mini-edition. Neptune City, USA, T.F.H. Publications, 992p.

Bertollo, L. A. C., C. S. Takahashi \& O. Moreira Filho. 1978. Cytotaxonomic considerations on Hoplias lacerdae (Pisces, Erythrinidae). Brazilian Journal of Genetics, 1: 103-120.

Bleher, H. 2006. Bleher's Discus. Miradolo Terme, Italy, Aquapress Publishers, v. 1, 671p.

Bleher, H., K. N. Stölting, W. Salzburger \& A. Meyer. 2007. Revision of the Genus Symphysodon Heckel, 1840 (Teleostei: Perciformes: Cichlidae) based on molecular and morphological characters. Aqua International Journal of Ichthyology, 13: 133-174.

Bull, J. J. \& J. M. Legler. 1980. Karyotypes of side-necked turtles (Testudines, Pleurodira). Canadian Journal of Zoology, 58(5): 828-841.

Centofante, L., J. I. R. Porto \& E. Feldberg. 2002. Chromosomal polymorphism in Serrasalmus spilopleura Kner, 1858 (Characidae, Serrasalminae) from Central Amazon Basin. Caryologia, 55: 37-45.

Chao, N. L. 2001. The fishery, diversity, and conservation of ornamental fishes in the rio Negro Basin, Brazil - A review of Project Piaba (1989-99). Pp. 161-204. In: Chao, N. L; G. Prang, L. Sonneschein \& M. Tlusty (Eds). Conservation and management of ornamental fish resources of the rio Negro Basin, Amazonia, Brazil - Project Piaba. Manaus, Editora da Universidade do Amazonas, 310p.

Degani, G. 2003. Genetic variations in strains of Discus (Symphysodon aequifasciata) using RAPD PCR. Israeli Journal of Aquaculture, 55: 86-93.

De Lucca, E. J. 1983. Microcromossomo: natureza, função e implicações evolutivas. Ciência e Cultura, 36(2): 268-273.

Denton, T. E. 1973. Fish chromosome methodology. Illinois, USA. Charles C. Thomas. Springfield, 166p.

Farias, I. P., G. Ortí \& A. Meyer. 2000. Total evidence: molecular, morphology, and the phylogenetics of cichlids fishes. Journal of Experimental Zoology, 288: 76-92.

Farias, I. P., G. Ortí, I. Sampaio, H. Schneider \& A. Meyer. 2001. The cytocrome $b$ gene as a phylogenetic marker: the limits of resolution for analyzing relationships among cichlid fishes. Journal of Molecular Evolution, 53: 89-103.

Feldberg, E., J. I. R. Porto \& L. A. C. Bertollo. 2003. Changes and adaptation of cichlids fishes during evolution. Pp.285-308. In: Val, A. L., Kapoor, B. G. Fish Adaptation. New Dehli \& New York, IBH \& Oxford, 418p.

Fillon, V., M. Morisson, R. Zoorob, C. Auffray, M. Douaire, J. Gellin \& A. Vignal. 1998. Identification of 16 chicken microchromosomes by molecular markers using two colors fluorescence in situ hybridization (FISH). Chromosome Research, 6: 307-313.

Goldschmidt, B., D. M. Nogueira, K. P. A. Silva \& L. M. Souza. 2000. Study of the karyotype of Oryzoborus maximiliani (Passeriformes, Aves) using young feather pulp cultures. Genetic and Molecular Biology, 23(2): 371-373.

Goldstein, R. J. 1973. Cichlids of the World. Neptune City, USA. T.F.H. Publications, 382p.

Gutierrez, J. M. \& R. Bolanos. 1980. Karyotype of the yellowbellied sea snake, Pelamis platurus. Journal of Herpetology, 14(2): 161-165.

Howell, W. M. \& D. A. Black. 1980. Controlled silver-staining of nucleolus organizer regions with a protective colloidal developer: a 1 -step method. Experientia, 36: 1014-1015.

Koh, T. L., G. Khoo, L. Q. Fan \& V. P. E. Phang. 1999. Genetic diversity among wild forms and cultivated varieties of discus (Symphysodon spp.) as revealed by random amplified polymorphic DNA (RAPD) fingerprinting. Aquaculture, 173: 485-497.

Kokoscha, V. M. \& H. Greven. 1996. Gibt es nur eine Art? Isoenzym-elektrophorese bei diskusfischen. DATZ Sonderheft Diskus: 20.

Kullander, S. O. 1998. A phylogeny and classification of the South American Cichlidae (Teleostei: Perciformes). Pp. 461-498. In: Malabarba L. R., R. E. Reis, R. P. Vari, Z. M. Lucena \& C. A. S. Lucena (Eds.). Phylogeny and Classification of Neotropical Fishes. Porto Alegre, Edipucrs, 603p.

Levan, A., K. Fredga \& A. A. Sandberg. 1964. Nomenclature for centromeric position on chromosomes. Hereditas, 52: 201-220.

Matthey, R. 1975. Identification of 16 chicken microchromosomes by molecular markers using two-colour fluorescence in situ hybridization (FISH). Chromosome Research, 6(4): 307-313.

Mazeroll, A. I. \& M. Weiss. 1995. The state of confusion in discus taxonomy. Pp.77-83. In: Konings, A. (Ed.). Cichlids Yearbook, vol. 5. Germany, Cichlid Press.

Ohno, S. \& N. B. Atkin. 1966. Comparative DNA values and chromosome complements of eight species of fishes. Chromosoma, 18: 455-466.

Ohno, S., J. Muramoto, C. Stenius, L. Christian, W. A. Kittrell \& N. B. Atkin. 1969. Microchromosomes in Holocephalian, Chondrostean and Holostean fishes. Chromosoma, 26: 35-40.

Ready, J. S., E. J. G. Ferreira \& S. O. Kullander. 2006. Discus fishes: mitochondrial DNA evidence for a phylogeographic barrier in the Amazonian genus Symphysodon (Teleostei: 
Cichlidae). Journal of Fish Biology, 69(B): 200-211.

Silva, T. \& B. Kotlar. 1980. Discus. Neptune City, USA.T.F.H. Publications. 96p.

Sumner, A. T. 1972. A simple technique for demonstrating centromeric heterochromatin. Experimental Cell Research, 74: 304-306.

Takai, A., T. Yoshikawa \& Y. Ojima. 2002. C-banded karyotype and nucleolus organizer regions in a discus fish, Symphysodon aequifasciata axelrodi (Cichlidae, Perciformes). Chromosome Science, 6: 53-55.

Tegelström, H., T. Ebenhard \& H. Ryttman. 1983. Rate of karyotype evolution and speciation in birds. Hereditas, 98: 235-239.

Tegelström, H. \& H. Ryttman. 1981. Chromosomes in birds: evolutionary implications of macro and microchromosome number and lengths. Hereditas, 94: 225-233.

Thompson, K. W. 1976. Some aspects of chromosomal evolution of the Cichlidae (Teleostei: Perciformes) with emphasis on Neotropical forms. Unpublished Ph.D. Dissertation. University of Texas at Austin, USA. 132p.

Thompson, K. W. 1979. Cytotaxonomy of 41 species of Neotropical Cichlidae. Copeia, 1979: 679-691.

Accepted February 2008

Published June 28, 2008 